\title{
Prevalence of peste des petits ruminants in the arid zone in the Republic of Niger
}

\begin{abstract}
Authors:
Souaibou Farougou

Mariama Gagara ${ }^{1}$

Guy A. Mensah²

Affiliations:

${ }^{1}$ Polytechnic School of

Abomey-Calavi, University

of Abomey-Calavi, Republic

of Benin
\end{abstract}

${ }^{2}$ Agricultural Research Centre of Agonkanmey, National Institute of Agricultural

Research of Benin, Republic of Benin

\section{Correspondence to:}

Souaibou Farougou

Email:

farougou@gmail.com

Postal address:

PO Box 2009, Main Recipe,

Cotonou 01, Republic of

Benin

Dates:

Received: 05 Dec. 2012

Accepted: 03 July 2013

Published: 09 Sept. 2013

How to cite this article:

Farougou, S., Gagara, M.

\& Mensah, G.A., 2013,

'Prevalence of peste des petits ruminants in the arid zone in the Republic of Niger', Onderstepoort Journal of Veterinary Research 80(1), Art. \#544, 6 pages. http://dx.doi.org/10.4102/ ojvr.v80i1.544

\section{Copyright:}

(C) 2013. The Authors.

Licensee: AOSIS

OpenJournals. This work

is licensed under the

Creative Commons

Attribution License.
The study aimed to determine the prevalence of peste des petits ruminants in the arid zone (Niamey, Tillabéry and Tahoua) of the Republic of Niger. A serological survey was conducted and 519 serum samples were collected from 253 unvaccinated sheep and 266 unvaccinated goats. The sample included 340 female animals (168 sheep and 172 goats) and 160 kids and lambs (78 lambs and 82 kids). A competitive enzyme-linked immunosorbent assay yielded an overall seroprevalence of $45.0 \%$. The prevalence in sheep was $42.0 \%$ compared with $47.9 \%$ in goats. The seroprevalence observed amongst small ruminants in Tahoua (49.8\%) and Tillabéry $(46.6 \%)$ was significantly higher $(p=0.001)$ than that observed in animals from Niamey $(25.1 \%)$. It was also higher $(p=0.04)$ in sheep younger than two years $(51.8 \%)$ than in adults $(37.6 \%)$. Conversely, the seroprevalence showed no significant difference between male animals $(35.8 \%$ in sheep; $50.1 \%$ in goats) and female animals (45.1\% in sheep; $46.4 \%$ in goats). The prevalence of the disease observed amongst the sheep and goat populations confirms the continued danger of this disease in the areas studied. It is therefore necessary to develop strategies such as improving livestock services, providing effective vaccines and implementing a vaccination programme for an effective control of the disease in sub-Saharan Africa.

\section{Introduction}

Small ruminants in the Republic of Niger contribute significantly to the gross domestic product of the country. Of the total of 80403 tons of meat produced in the country, small ruminants contribute 29709 tons, about 37.0\% (Countrystat 2012).

Compared with the studies carried out on cattle, current knowledge of small ruminant diseases is fragmentary and incomplete. The persistence of, amongst others, peste des petits ruminants (PPR) is explained by the essentially transhumant mode of livestock management and low immunisation coverage. Only $16.4 \%$ of the sheep and $14.2 \%$ of the goat population are vaccinated against PPR (Countrystat 2012).

PPR is an infectious and highly contagious viral disease of wild and domesticated small ruminants. It is characterised by digestive disorders, erosive stomatitis and necrotising pneumonia (Jones et al. 1993) and can be controlled by vaccination, quarantine and disinfection (Chen et al. 2010; Diallo et al. 2007; Jones et al. 1993).

The geographical distribution of PPR includes sub-Saharan Africa, the Middle East (Abu-Elzein et al. 1990; Lefevre et al. 1991; Taylor 1984; Taylor, Al Busaidy \& Barrett 1990) and the Indian subcontinent (Kwiatek et al. 2007; Shaila et al. 1996; Taylor et al. 2002).

PPR is caused by a virus belonging to the genus Morbillivirus (Gibbs et al. 1979). Often manifesting in epizootic form, it is of vital economic importance because of its associated high mortality rate. In spite of the direct and indirect losses caused by PPR in animal husbandry in the Republic of Niger, few studies have been conducted to determine its epidemiological parameters such as animal movements, management issues (Bloch \& Diallo 1991) and introduction of animals that are important in PPR transmission and its persistence. The purpose of this study was to assess the seroprevalence of PPR in the arid zone in Niamey, Tahoua and Tillabéry in the Republic of Niger.

\section{Materials and methods}

\section{Study areas}

Out of the eight regions that make up the Republic of Niger, Niamey, Tillabéry and Tahoua (Figure 1) were selected because of reports of alleged cases of PPR. In Tahoua and Tillabéry, five districts were randomly selected for the purpose of this study, whilst in Niamey, three districts were selected. 


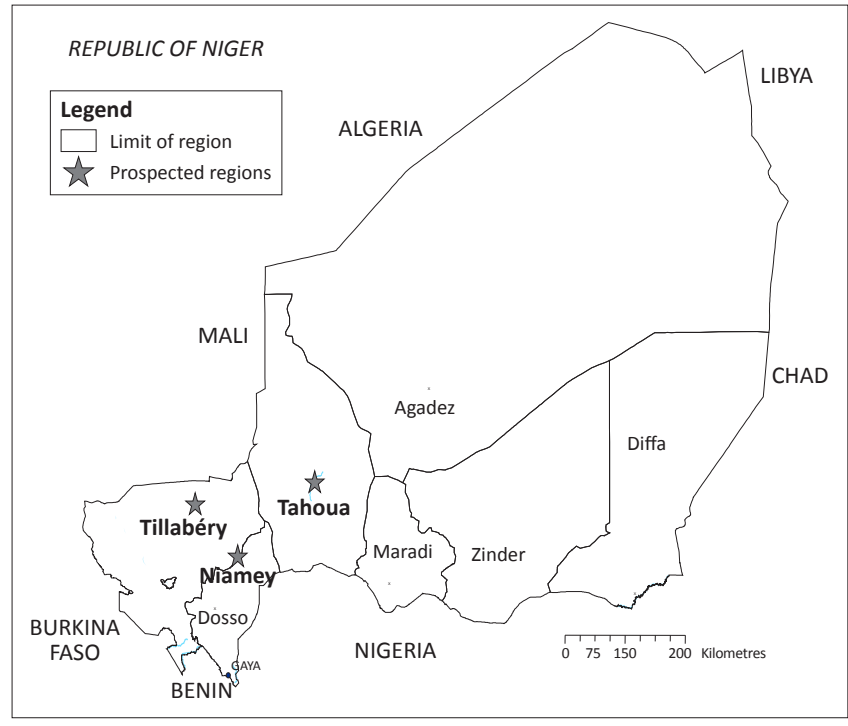

FIGURE 1: Location of farms surveyed in the Republic of Niger.

The three regions combined contain $37.0 \%$ of the sheep and $32.0 \%$ of the goat populations. Local livestock are kept under semi-intensive conditions and graze pastures during the rainy season (June to September; rainfall $=200 \mathrm{~mm}-900 \mathrm{~mm}$ ). Hay is provided during the dry season (October to May). The diet is supplemented with agro-industrial and food byproducts such as corn bran, rice bran, millet bran, sorghum bran and brewer's spent grain, as well as vitamin and mineral supplements in the form of salt licks. Animals get water ad libitum from the rivers and have access to open shelters all year round, except for those meant for fattening and pregnant or lactating female animals, which are kept in covered shelters. Average weather data for the sample collection period are provided in Table 1.

\section{Blood sample collection}

The samples were collected randomly from 15-20 small ruminants per breeding unit in the districts of Tahoua and Tillabéry and from 8-10 small ruminants in the district of Niamey, where fewer small ruminants occur.

Blood samples of sheep and goats were collected over four months (November to February) during the dry season, when a resurgence of various animal diseases, including PPR, is generally reported by veterinary service workers. We collected a total of 519 blood samples from unvaccinated sheep and goats (according to the veterinary office) in selected districts of Niamey (Niamey I, III and V), Tahoua (BirniN'Konni, Illela, Abalak, Madoua, Bambay) and Tillabéry (N’Dounga, Fakara, Bani Bangou, Kokoro, Tabala) (Table 2).

Samples were organised according to age (animals younger than two years vs animals older than two years). Information gathered from farmers as well as the dentition helped to determine the ages of the animals.

Blood samples were collected in plain Vacutainer tubes. After centrifugation the resulting serum was transferred to mictotubes and frozen at $-20{ }^{\circ} \mathrm{C}$ until analysis. Each tube was marked by codes that represented information of the location of the breeder and the age and sex of the animals.

During the collection of blood samples, special attention was given to animals showing signs of suspected PPR. In such cases, a nasal swab was taken for further analysis by polymerase chain reaction (PCR) to confirm PPR. A total of 26 such blood samples were collected from animals in the four regions surveyed.

\section{Laboratory analysis of blood samples}

Serum samples were analysed for PPR antibodies at the Department of Niger Veterinary Laboratories, using a competitive enzyme-linked immunosorbent assay (ELISA). Competitive ELISA kits of CIRAD (EMVT, France) and the Pirbright Institute (United Kingdom) were used in this study. The analyses were performed in accordance with the procedure described by Libeau et al. (1995), Choi et al. (2005) and Wang et al. (2007). Optical densities were read in a spectrophotometer at $492 \mathrm{~nm}$.

The mean inhibition percentage of a serum sample was calculated from two wells. Samples with an inhibition percentage higher than $50.0 \%$ were considered positive (Aslam et al. 2009; Zahur et al. 2011). The competitive ELISA kit used for the diagnosis of PPR had a sensitivity and specificity of $92.2 \%$ and $98.4 \%$, respectively, compared with the test virus neutralisation standard (Gopilo 2005).

The detection of viral RNA by reverse transcriptase PCR (RT-PCR) was performed in accordance with the method described by Bao et al. (2008) and Couacy-Hymann et al. (2002). Viral RNA was extracted from nasal swabs using the RNeasy Mini Kit (QIAGEN, Courtaboeuf, France) according to the manufacturer's instructions.

TABLE 1: Weather data for the study area.

\begin{tabular}{|c|c|c|c|c|c|c|c|}
\hline \multirow[t]{2}{*}{ Region } & \multirow[t]{2}{*}{ Weather data } & \multicolumn{6}{|c|}{ Month } \\
\hline & & November & December & January & February & March & April \\
\hline \multirow[t]{3}{*}{ Tahoua } & Average temperature $\left({ }^{\circ} \mathrm{C}\right)$ & 26.7 & 23.5 & 22.4 & 25.4 & 29.5 & 33.0 \\
\hline & Average precipitation (mm) & 0.0 & 0.0 & 0.0 & 0.0 & 1.0 & 4.0 \\
\hline & Relative humidity (\%) & 32.0 & 27.0 & 23.0 & 19.0 & 18.0 & 26.0 \\
\hline \multirow[t]{3}{*}{ Niamey } & Average temperature $\left({ }^{\circ} \mathrm{C}\right)$ & 27.8 & 24.9 & 24.3 & 27.6 & 30.9 & 33.8 \\
\hline & Average precipitation $(\mathrm{mm})$ & 0.0 & 0.0 & 0.0 & 0.0 & 3.0 & 7.0 \\
\hline & Relative humidity (\%) & 34.9 & 26.6 & 22.0 & 17.1 & 17.7 & 28.1 \\
\hline \multirow[t]{3}{*}{ Tillabéry } & Average temperature $\left({ }^{\circ} \mathrm{C}\right)$ & 27.8 & 24.9 & 24.2 & 26.9 & 30.3 & 33.1 \\
\hline & Average precipitation (mm) & 0.0 & 0.0 & 0.0 & 0.0 & 2.0 & 5.0 \\
\hline & Relative humidity (\%) & 32.0 & 25.0 & 22.0 & 19.0 & 22.0 & 26.0 \\
\hline
\end{tabular}


For PCR, a pair of primers amplifying a fragment of $351 \mathrm{bp}$ (NP3: 5'-CGG TCT AGA AAA TCG CTC CAC CTG-3' and NP4: 5'-CCT CTC CTC CCT GGT CCA GAA TCT-3') was used (Couacy-Hymann et al. 2002). An aliquot of $25 \mu \mathrm{L}$ of the amplification mixture contained $1 \mu \mathrm{L}$ of each primer ( $5 \mathrm{pmol} / \mathrm{L}$ ), $5 \mu \mathrm{L}$ of cDNA, $1 \mu \mathrm{L}$ of deoxyribonucleotide triphosphate $(\mathrm{dNTP}), 5 \mu \mathrm{L}$ of $5 \times$ buffer, $1 \mu \mathrm{L}$ of Taq polymerase $(1.25 \mathrm{U} / \mathrm{L})$ and $12 \mu \mathrm{L}$ of sterile distilled water. After an initial denaturation at $95^{\circ} \mathrm{C}$ for $5 \mathrm{~min}$, amplification proceeded with 29 cycles of denaturation at $94^{\circ} \mathrm{C}$ for $30 \mathrm{~s}, 30$ S of annealing at $55^{\circ} \mathrm{C}$ and an extension phase at $72{ }^{\circ} \mathrm{C}$ for 1 $\mathrm{min}$, followed by a final extension of $5 \mathrm{~min}$ at $72{ }^{\circ} \mathrm{C}$.

The PCR products were visualised after electrophoresis on $1.5 \%$ agarose gel. The samples that had been analysed by

TABLE 2: Distribution of samples by region.

\begin{tabular}{lcccccc}
\hline Region & \multicolumn{2}{c}{ Total number of small ruminants $^{\mathbf{a}}$} & & \multicolumn{2}{c}{$\begin{array}{c}\text { Number of collected serum } \\
\text { samples }\end{array}$} \\
\cline { 2 - 3 } \cline { 6 - 7 } & Sheep & Goats & & Sheep & Goats \\
\hline Tillabéry & 1433449 & 1633696 & & 184 & 122 \\
Niamey & 153848 & 84702 & & 25 & 36 \\
Tahoua & 2193239 & 2350491 & & 44 & 108 \\
\hline Total & $\mathbf{3 7 8 0 5 3 6}$ & $\mathbf{4 0 6 8 8 8 9}$ & & $\mathbf{2 5 3}$ & $\mathbf{2 6 6}$ \\
\hline
\end{tabular}

a adapted from Countrystat, 2012, Livestock - Total number of living animals by administrative level 1, product and year, viewed 31 August 2012, from http://www.countrystat.org/ner/cont/ pxwebquery/ma/158spd035/fr

TABLE 3: Prevalence of peste des petits ruminants in sheep and goats according to location.

\begin{tabular}{llcccc}
\hline Animal type & Variable & Tillabéry & Tahoua & Niamey & Total \\
\hline Sheep & Number of samples & 184 & 44 & 25 & 253 \\
& Positive cases & 75 & 25 & 5 & 105 \\
& Positive cases (\%) & $40.8 \dagger$ & 56.8 & 20.0 & 41.5 \\
& TP (\%) & 41.3 & 57.3 & 20.51 & 42 \\
Goats & Number of samples & 122 & 108 & 36 & 266 \\
& Positive cases & 66 & 50 & 10 & 126 \\
& Positive cases (\%) & 54.1 & 46.3 & 27.8 & 47.4 \\
& TP (\%) & 54.6 & 46.8 & 28.3 & 47.9 \\
\hline Total & p-value & $\mathbf{0 . 0 2}$ & $\mathbf{0 . 2 6}$ & $\mathbf{0 . 4 8}$ & $\mathbf{0 . 1 1}$ \\
& Number of samples & $\mathbf{3 0 6}$ & $\mathbf{1 5 2}$ & $\mathbf{6 1}$ & $\mathbf{5 1 9}$ \\
& Positive cases & $\mathbf{1 4 1}$ & $\mathbf{7 5}$ & $\mathbf{1 5}$ & $\mathbf{2 3 1}$ \\
& Positive cases (\%) & $\mathbf{4 6 . 1}$ & $\mathbf{4 9 . 3}$ & $\mathbf{2 4 . 6}$ & $\mathbf{4 4 . 5}$ \\
& TP (\%) & $\mathbf{4 6 . 6 ^ { \mathrm { a } }}$ & $\mathbf{4 9 . 8 ^ { \mathrm { a } }}$ & $\mathbf{2 5 . 1 ^ { \mathrm { b } }}$ & $\mathbf{4 5 . 0}$ \\
\hline
\end{tabular}

$\dagger$, apparent prevalence; TP, true prevalence

${ }^{a}$ and ${ }^{b}$, indicate significant differences. Values on the same line followed by the same superscript letters were not statistically different $(p>0.05)$
PCR were considered positive if a DNA fragment of $351 \mathrm{bp}$ was obtained.

\section{Statistical analyses}

Collected data were entered into a spreadsheet according to sex and age for each locality. The apparent prevalence of PPR was calculated by dividing the number of positive samples by the total number of samples tested. The true prevalence was estimated using the method of Rogan and Gladen (1978). The Z bilateral test included in the STATISTICA software package (Statistica 2003) was used to compare the prevalences. Differences were considered significant at $p<0.05$.

\section{Results}

\section{Overall prevalence of peste des petits ruminants}

Of the 519 blood samples processed by serology, 231 tested positive for PPR, representing a prevalence of $45.0 \%$. The prevalence in goats was 5.9\% higher than in sheep, although this was not a significant difference $(p=0.11)$ (Table 3).

\section{Prevalence of peste des petits ruminants according to location}

The prevalence of PPR in sheep and goats varied between sampling areas (Table 3). Except for the Tahoua region, the true prevalence in goats was higher than in sheep. The prevalence in the Tahoua region was $24.7 \%$ higher $(p<0.001)$ than for the Niamey region. Although the prevalence was $3.2 \%$ higher than for the Tillabéry region, the difference was not statistically significant. However, the prevalence of PPR determined in the Tillabéry region was $21.5 \%$ higher than that found for the Niamey region $(p<0.001)$.

\section{Prevalence of peste des petits ruminants according to age}

In all regions, the prevalence of PPR in sheep younger than two years was higher than in both sheep and goats older than two years (Table 4). In the Tillabéry and Niamey regions, positive cases and prevalences in goats younger than two years

TABLE 4: Prevalence of peste des petits ruminants in sheep and goats according to age

\begin{tabular}{|c|c|c|c|c|c|c|c|}
\hline \multirow{2}{*}{$\begin{array}{l}\text { Sampling area } \\
\text { Tillabéry }\end{array}$} & \multirow{2}{*}{$\begin{array}{l}\text { Variable } \\
\text { Age }\end{array}$} & \multicolumn{2}{|c|}{ Sheep } & \multirow{2}{*}{$\begin{array}{c}p \text {-value } \\
-\end{array}$} & \multicolumn{2}{|c|}{ Goats } & \multirow{2}{*}{$\begin{array}{c}p \text {-value } \\
-\end{array}$} \\
\hline & & $<2$ years & $>2$ years & & $<2$ years & $>2$ years & \\
\hline & Number of samples & 61 & 123 & - & 30 & 92 & - \\
\hline & Positive cases & 31 & 44 & - & 22 & 44 & - \\
\hline & Positive cases (\%) & $50.8 \dagger$ & 35.8 & - & 73.3 & 47.8 & - \\
\hline & TP & 51.3 & 36.3 & 0.05 & 73.4 & 48.3 & 0.02 \\
\hline \multirow[t]{4}{*}{ Tahoua } & Number of samples & 10 & 34 & - & 40 & 68 & - \\
\hline & Positive cases & 7 & 18 & - & 16 & 34 & - \\
\hline & Positive cases $(\%)$ & 70.0 & 52.9 & - & 40.0 & 50.0 & - \\
\hline & TP & 70.5 & 53.4 & 0.34 & 53.0 & 56.4 & 0.76 \\
\hline \multirow[t]{4}{*}{ Niamey } & Number of samples & 7 & 18 & - & 12 & 24 & - \\
\hline & Positive cases & 2 & 3 & - & 5 & 5 & - \\
\hline & Positive cases (\%) & 28.6 & 16.7 & - & 41.7 & 20.8 & - \\
\hline & TP & 29.1 & 17.2 & 0.51 & 42.2 & 21.3 & 0.19 \\
\hline \multirow[t]{4}{*}{ Total } & Number of samples & 78 & 175 & - & 82 & 184 & - \\
\hline & Positive cases & 40 & 65 & - & 43 & 83 & - \\
\hline & Positive cases (\%) & 51.3 & 37.1 & - & 52.4 & 45.1 & - \\
\hline & TP & 51.8 & 37.6 & 0.04 & 52.9 & 45.6 & 0.29 \\
\hline
\end{tabular}

$\dagger$, apparent prevalence; TP, true prevalence 
TABLE 5: Prevalence of peste des petits ruminants in sheep and goats according to sex.

\begin{tabular}{|c|c|c|c|c|c|c|c|}
\hline \multirow{2}{*}{$\begin{array}{l}\text { Region } \\
\text { Tillabéry }\end{array}$} & \multirow{2}{*}{$\begin{array}{l}\text { Variable } \\
\text { Sex }\end{array}$} & \multicolumn{2}{|c|}{ Sheep } & \multirow{2}{*}{$\begin{array}{c}p \text {-value } \\
-\end{array}$} & \multicolumn{2}{|c|}{ Goats } & \multirow{2}{*}{$\frac{p \text {-value }}{-}$} \\
\hline & & Male & Female & & Male & Female & \\
\hline & Number of samples & 62 & 122 & - & 41 & 81 & - \\
\hline & Positive cases & 20 & 55 & - & 23 & 43 & - \\
\hline & Positive cases (\%) & $32.3 \dagger$ & 45.1 & - & 56.1 & 53.1 & - \\
\hline & TP & 32.8 & 45.6 & 0.06 & 56.6 & 53.6 & 0.75 \\
\hline \multirow[t]{4}{*}{ Tahoua } & Number of samples & 15 & 29 & - & 36 & 72 & - \\
\hline & Positive cases & 8 & 17 & - & 20 & 30 & - \\
\hline & Positive cases (\%) & 53.3 & 58.6 & - & 55.6 & 41.7 & - \\
\hline & TP & 53.8 & 59.1 & 0.75 & $56.1^{a}$ & $42.2^{\mathrm{a}}$ & 0.17 \\
\hline \multirow[t]{4}{*}{ Niamey } & Number of samples & 8 & 17 & - & 17 & 19 & - \\
\hline & Positive cases & 2 & 3 & - & 4 & 6 & - \\
\hline & Positive cases (\%) & 25.0 & 17.7 & - & 25.5 & 31.6 & - \\
\hline & TP & 25.5 & 18.2 & 0.68 & 24.0 & 32.1 & 0.59 \\
\hline \multirow[t]{3}{*}{ Total } & Number of samples & 85 & 168 & - & 94 & 172 & - \\
\hline & Positive cases (\%) & 35.3 & 44.6 & - & 50.0 & 45.9 & - \\
\hline & TP & 35.8 & 45.1 & 0.17 & 50.5 & 46.4 & 0.43 \\
\hline
\end{tabular}

$\dagger$, apparent prevalence; TP, true prevalence

a, Superscripted letters indicate significant differences. Values on the same line followed by the same superscript letters were not statistically different $(p>0.05)$

were higher than in goats older than two years (Table 4). The PPR prevalence amongst young small ruminants (52.4\%; $n=359)$ was significantly higher than in adults $(40.9 \%$; $n=160)$.

\section{Prevalence of peste des petits ruminants according to sex}

Except for the Niamey region, the prevalence of PPR in female sheep was higher (although not significantly) than in male sheep in all regions (Table 5). However, the particularity of the Niamey results can be explained by the small sample size collected in this region. The prevalence in male goats was higher, but not significantly, than in female goats in all regions, except for the Niamey region (Table 5). The overall prevalence found amongst female animals was $45.8 \%$ $(n=179)$, which was not significantly different from that in male animals $(43.5 \% ; n=340)$.

\section{Polymerase chain reaction analysis}

The PCR analysis of samples from nasal swabs confirmed the presence of the PPR virus (Figure 2). Of the 26 samples analysed, eight were positive. The PCR results in these animals confirmed those of serological analyses.

\section{Discussion}

The prevalence of PPR (45.0\% for all sera tested) was investigated in north-western Niger (Tahoua, Niamey and Tillabéry) and is close to that observed in other regions in Africa. In Mali, Tounkara et al. (1996) and Sangare et al. (2007) found prevalences of $32.0 \%$ and $37.0 \%$, respectively, whilst Awa et al. (2002) found a prevalence of $30.0 \%$ in Cameroon.

These results could be accounted for by the fact that in arid and semi-arid areas where PPR develops in an enzootic manner, cases generally appear only when other factors contribute to a weakening in the animals. In the Republic of Niger, cold weather conditions from November to February

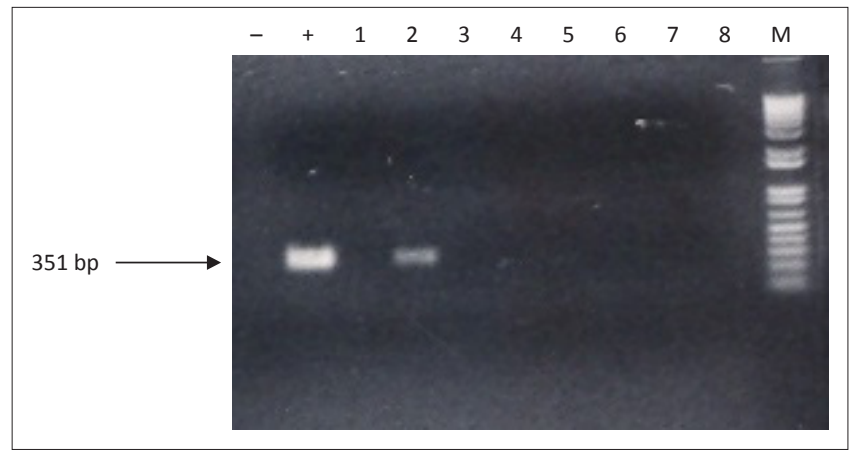

M, molecular weight marker; +, positive control; -, negative control.

Note: Tested samples are shown in columns 1-8; positive samples are shown in columns 1-4; Primers NP3 and NP4 which amplify a sequence of 351 base pairs (bp), were used FIGURE 2: Agarose gel $(1.5 \% \mathrm{~W} / \mathrm{V})$ of the polymerase chain reaction amplification products performed on nasal swabs.

and low temperatures predispose animals to lung diseases. During this period, pastures are virtually non-existent and the resulting shortage of food lessens the resistance of animals, thus making them susceptible to various diseases.

The seroprevalence in other regions is lower than found in our study. In fact, prevalences below 30.0\% have been noted in many regions of the world. For example, a seroprevalence of $28.9 \%$ was observed in northern Burkina Faso (Sow et al. 2008), 24.0\% in Oman (Taylor et al. 1990), 22.4\% in Turkey (Özkul et al. 2002), 19.0\% in Côte d'Ivoire (Couacy-Hymann et al. 2002) and $10.0 \%$ in Ethiopia (Abraham et al. 2005).

The present study showed that the PPR seroprevalence was slightly higher in goats $(47.9 \%)$ than in sheep $(42.0 \%)$ although the difference was not significant. This trend is consistent with that observed in Cameroon (Awa et al. 2002), where the seroprevalence in goats $(44.0 \%)$ was higher than that observed in sheep (29.0\%). The same trend is observed in Pakistan, where Khan et al. (2007) found a higher seropositivity in goats (51.2\%) than in sheep (39.0\%). In north-western Mali, Sangare et al. (2007) noted a seroprevalence of $44.0 \%$ in goats and $34.0 \%$ in sheep. However, these results contradict those 
noted by Sow et al. (2008) in northern Burkina Faso, where the seroprevalence was $33.1 \%$ in sheep and $23.0 \%$ in goats. In Turkey, seroprevalences of $29.2 \%$ and $20.0 \%$ were found in sheep and goats, respectively (Özkul et al. 2002). In Ethiopia, Abraham et al. (2005) found a prevalence of $13.0 \%$ in sheep and $9.0 \%$ in goats.

These varying results show that the sensitivity to PPR is not necessarily linked to the given species of small ruminants, but rather to rearing conditions and other individual factors.

Furthermore, it appears from the study that the seroprevalence of PPR varies according to area. The prevalence noted amongst sheep and goats was much higher in Tahoua (49.8\%) and Tillabéry (46.6\%) than in Niamey (25.1\%). The relatively high prevalence in Tahoua and Tillabéry could be due to a higher number of PPR-affected animals from which blood samples were collected.

The overall seroprevalence found amongst female animals was $45.8 \%$, which was not significantly different from that found in male animals.

The PPR seroprevalence amongst young animals (51.8\%) was much higher than amongst adults $(42.0 \%)$. This can be accounted for by the fact that the susceptibility of animals to infection by the PPR virus is linked to age (Lefevre 1991). Young animals (between 2 and 18 months old) seem more prone to PPR than adults. These results are not consistent with those by Sow et al. (2008), who noted a prevalence of $33.4 \%$ in adults compared with $28.0 \%$ in young animals. Tounkara et al. (1996) further noted that the PPR seroprevalence is higher in older small ruminants because in an enzootic area they are more prone to contamination by the virus. PCR analyses confirmed the presence of the PPR virus in surveyed farms. Similar results were obtained by Balamurugan et al. (2006).

\section{Conclusion}

This study showed that the seroprevalence of PPR is relatively high (45.0\%) amongst sheep and goats in the northwestern region of the Republic of Niger. Precarious breeding conditions, malnutrition and nutritional deficiencies due to an uncertain rainy season and harsh climates (intense cold and dust) are, to a large extent, the predisposing factors.

In a country where farming contributes greatly to the gross domestic product, it is important to protect livestock against diseases associated with serious economic impact, such as PPR. However, the Republic of Niger is currently confronted with conflicting issues, marked by rapid population growth and an increasing need for animal protein without the resources allocated to the health improvement of livestock being adjusted accordingly. These elements make research and development choices complex and difficult. Priority themes and strategies should be adapted, taking into account the prevailing disease conditions and means of intervention.
Given the economic imperatives, sound decisions should be made to allocate funds to activities that would have an optimal positive impact on livestock productivity in a short period. The fight against PPR plays a significant role in this regard. Further work should investigate the role of other pathogens and environmental risk factors in the spread of the disease to improve the understanding of the emergence of the disease and its socio-economic impact.

\section{Acknowledgments}

The authors would like to thank Dr. Issoufou Maikano, his team of the directorate of Veterinary Laboratory and the Karkara NGOs agents for their contribution to the realisation of this study.

\section{Competing interests}

The authors declare that they have no financial or personal relationship(s) that may have inappropriately influenced them in writing this article.

\section{Authors' contributions}

S.F. (University of Abomey-Calavi) was the project leader, M.G. (University of Abomey-Calavi) performed most of the experiments and G.A.M. (National Institute of Agricultural Research, Benin) contributed to the writing of the manuscript.

\section{References}

Abraham, G., Sintayehu, A., Libeau, G., Albin, A., Roger, F., Laekemaryam, Y. et al., 2005, 'Antibody seroprevalence against Peste des Petits Ruminants (PPR) virus in
camels, cattle, goats and sheep in Ethiopia', Preventative Veterinary Medicine 70 , camels, cattle, goats and sheep in Ethiopia', Preventative Veterinary Medicine 70,1006 .
51-57. http://dx.doi.org/10.1016/j.prevetmed.2005.02.011, PMid:15967242

Abu-Elzein, E.M.E., Hassanien, M.M., Al-Afaleq, A.I., Abdelhadi, M.A. \& Honsawai, F.M.J., 1990, 'Isolation of peste des petits ruminants from goats in Saudi Arabia', Veterinary Record 127, 309-310. PMid:2238415

Aslam, M., Muhammad, A., Anjum, R., Saleha, S. \& Ali, Q., 2009, 'Prevalence of Peste Des Petits Ruminants Virus (PPRV) in Mardan, Hangu and Kohat District of Pakistan: Comparative analysis of PPRV suspected serum samples using Competitive ELISA (cELISA) and Agar Gel Immunodiffusion (AGID)', Veterinary World 2, 89-92. http:// dx.doi.org/10.5455/vetworld.2009.89-92

Awa, D.N., Ngagnou, A., Tefiang, E., Yaya, D. \& Joyan, A., 2002, 'Post vaccination and colostral peste des petits ruminants antibody dynamics in research flocks of north Cameroon', Preventive Veterinary Medicine 55, 267-271. http://dx.doi.org/10.1016/ S0167-5877(02)00013-2

Balamurugan, V., Sen, A., Saravanan, P., Singh, R.P., Singh, R.K., Rasool, T.J. et al., 2006 'One-step Multiplex RT-PCR Assay for the detection of Peste des petits ruminants virus in clinical samples', Veterinary Research Communications 30, 655-666. http:// dx.doi.org/10.1007/s11259-006-3331-3, PMid:16838207

Bao, J., Li, L., Wang, Z., Barrett, T., Suo, L., Zhao, W. et al., 2008, 'Development of one-step real-time RT-PCR assay for detection and quantitation of peste des petits ruminants virus', Journal of Virological Methods 148, 232-236. http://dx.doi. org/10.1016/j.jviromet.2007.12.003, PMid:18243345

Bloch, N. \& Diallo, I., 1991, 'Serological survey in small ruminants in four departments of Niger', Revue d'Elevage et de Médecine Vétérinaire des Pays Tropicaux 44 397-404. PMid:1843821

Chen, W., Hu, S., Qu, L., Hu, Q., Zhang, Q., Zhi, H et al., 2010, 'A goat poxvirusvectored peste-des-petits-ruminants vaccine induces long-lasting neutralization antibody to high levels in goats and sheep', Vaccine 28, 4742-4750. http://dx.doi org/10.1016/j.vaccine.2010.04.102, PMid:20471441

Choi, K-S., Nah, J-J., Ko, Y-J., Kang, S-Y. \& Jo, N-I., 2005, 'Rapid Competitive EnzymeLinked Immunosorbent Assay for detection of antibodies to Peste des Petits Ruminants Virus', Clinical and Diagnostic Laboratory Immunology 12, 542-547. PMid:15817764, PMCid:PMC1074382

Couacy-Hymann, E., Roger, F., Huard, C., Guillou, J.P., Libeau, G. \& Diallo A., 2002 'Rapid and sensitive detection of peste des petits ruminants virus by a Polymerase Chain Reaction assay', Journal of Virological Methods 100, 17-25. http://dx.doi. org/10.1016/S0166-0934(01)00386-X

Countrystat, 2012, Livestock - Total number of living animals by administrative level 1 product and year, viewed 31 August 2012, from http://www.countrystat.org/ner/ cont/pxwebquery/ma/158spd035/fr 
Diallo, A., Minet, C., Le Goff, C., Berhe, G., Albina, E., Libeau, G. et al., 2007, 'The threat of peste des petits ruminants: Progress in vaccine development for disease control', Vaccine 25, 5591-5597. http://dx.doi.org/10.1016/j.vaccine.2007.02.013, control', Vaccine

Gibbs, E.P.J., Taylor, W.P., Lawman, M.J.P. \& Bryant J., 1979, 'Classification of peste des petits ruminants virus as the fourth member of the genus Morbillivirus', Intervirology 11, 268-274. http://dx.doi.org/10.1159/000149044, PMid:457363

Gopilo, A., 2005, 'Epidemiology of peste des petits ruminants virus in Ethiopia and molecular studies on virulence', Ph.D thesis, National Polytechnic Institute, Toulouse.

Jones, L., Giavedoni, L., Saliki, J.T., Brown, C., Mebus, C. \& Yilma T., 1993, 'Protection of goats against peste des petits ruminants with a vaccinial virus double recombinant expressing the $\mathrm{F}$ and $\mathrm{H}$ genes of rinderpest virus', Vaccine 11, 961-964. http:// dx.doi.org/10.1016/0264-410X(93)90386-C

Khan, H.A., Siddique, M., Arshad, M.J., Khan, Q.M. \& Rehman, S.U., 2007, 'Seroprevalence of PPR in sheep and goats of Punjab province of Pakistan', Pakistan Veterinary Journal 27, 109-112.

Kwiatek, O., Minet, C., Grillet, C., Hurardy, C., Carlssonz, E., Karimovz, B. et al., 2007, 'Peste des Petits Ruminants (PPR) outbreak in Tajikistan', Journal of Comparative Pathology 136, 111-119. http://dx.doi.org/10.1016/j.jcpa.2006.12.002, PMid:17321539

Lefevre, P.C., 1991, 'Expanding disease: The PPR', Revue Mondiale de Zootechnie 66, 55-58.

Lefevre, P.C., Diallo, A., Schenkel, F., Hussein, S. \& Staak, G., 1991, 'Serological evidence of peste des petits ruminants in Jordan', Veterinary Record 128, 110. http://dx.doi. org/10.1136/vr.128.5.110, PMid:2024417

Libeau, G., Prehaud, C., Lancelot, R., Colas, F., Guerre, L., Bishop, D.H. et al., 1995 'Development of a competitive ELISA for detecting antibodies to the peste des petits ruminants virus using a recombinant nucleoprotein', Research in Veterinary Science 58, 50-55. http://dx.doi.org/10.1016/0034-5288(95)90088-8

Özkul, A., Akca, Y., Alkan, F., Barrett, T., Karaoglu, T., Dagalp, S.B. et al., 2002, 'Prevalence, distribution and host range of peste des petits ruminants virus, Turkey', Emerging Infectious Diseases 8, 708-712. http://dx.doi.org/10.3201/eid0807.010471 PMid:12095439, PMCid:PMC2730320
Rogan, W.J. \& Gladen, B., 1978, 'Estimation of prevalence from the results of a screening test', American Journal of Epidemiology 107, 71-76. PMid:623091

Sangare, O., Guitian, J., Samake, K., Kamissoko, B., Niang, M., Libeau, G. et al., 2007, 'Serological survery of peste des petits ruminants in north west Mali', Revue d'Elevage et de Médecine Vétérinaire des Pays Tropicaux 49, 273-277. http://dx.doi. org/10.1016/0168-1702(96)01312-3

Shaila, M., Shamaki, D., Forsyth, M.A., Diallo, A., Goatley, L., Kitching, R.P. et al., 1996, 'Geographic distribution of peste des petits ruminants viruses', Virus Research 43 149-153.

Sow, A., Ouattara, L., Compaore, Z., Doulkom, B.R., Pare, M., Poda, G. et al., 2008 'Seroprevalence of PPR in Soum province in northern Burkina Faso', Revue d'Elevage et de Médecine Vétérinaire des Pays Tropicaux 61, 5-9.

Statistica version 6.0, 2003, computer software. StatSoft, Tulsa, Oklahoma.

Taylor, W.P., 1984, 'The distribution and epidemiology of peste des petits ruminants', Preventive Veterinary Medicine 2, 157-166. http://dx.doi.org/10.1016/01675877(84)90059-X

Taylor, W.P., Al Busaidy, S. \& Barrett, T., 1990, 'The epidemiology of peste des petits ruminants in the Sultanate of Oman', Veterinary Microbiology 22, 341-352. http:// dx.doi.org/10.1016/0378-1135(90)90021-M

Taylor, W.P., Diallo, A., Gopalakrishna, S., Sreeramalu, P., Wilsmore, A.J., Nanda, Y.P. et al., 2002, 'Peste des petits ruminants has been widely present in Southern India since, if not before, the late 1980s', Preventive Veterinary Medicine 52, 305-312. $\mathrm{http}: / / \mathrm{dx}$.doi.org/10.1016/S0167-5877(01)00254-9

Tounkara, K., Traore, A., Sidibe, S., Samake, K., Diallo, B.O. \& Diallo, A., 1996, 'Epidemiology of peste des petits ruminants (PPR) and rinderpest in Mali: Serological surveys', Revue d'Elevage et de Médecine Vétérinaire des Pays Tropicaux 49, 273-271. PMid:9239932

Wang, Z., Bao, J., Wu, X., Liu, Y., Li, L., Liu, C. et al., 2007, 'Peste des Petits Ruminants Virus in Tibet, China', Emerging Infectious Diseases 15, 299-301. http://dx.doi. org/10.3201/eid1502.080817, PMCid:PMC2657621

Zahur, A.B., Ullah, A., Hussain, M., Irshad, H., Hameed, A., Jahangir, M. et al., 2011, 'Seroepidemiology of peste des petits ruminants (PPR) in Pakistan', Preventive Veterinary Medicine 102, 87-92. http://dx.doi.org/10.1016/j.prevetmed.2011.06.011 PMid:21788090 